\title{
4 Climate change and the threat to food production in Southern Africa
}

\author{
Paul L.G. Vlek, Eugene R. Terry \\ and Richard A. Sikora
}

\section{Climate change and its impact}

Climate change in Southern Africa is having an impact on life and livelihoods, and farmers are struggling to cope with its impact. Both, floods and droughts have increased in frequency and intensity and the onset of the rainy season has shifted and has become less predictable. In 2017, the Southern African Development Community (SADC) published a handbook entitled Climate Risk and Vulnerability (Davis-Reddy and Vincent, 2017) with up-to-date climatic analysis and projections for Southern Africa, which is used extensively in the following section.

Average land-surface temperature has increased across Africa over the last decennia, particularly since the 1970 s, and is continuing today (Figure 4.1). The subtropical Southern African region is among the most affected with a trend of $0.4{ }^{\circ} \mathrm{C}$ per decade. The rate of change in temperature over Africa is more than twice the global estimate (Osborn and Jones, 2014).

Trends in rainfall for Southern Africa are masked by the high variability and the lack of observational data in the region. The data for 1900 to 2014 (Harris et al., 2013), represented in Figure 4.2, show this high variability with some clear drought periods. The 2000s were wetter for most of the region except for the countries along the southwestern coast of Africa and the eastern coastline of Tanzania.

Trends in extreme events sumarized in Figure 4.3, are difficult to discern. However, the number of hot extremes have increased and the number of cold extremes have decreased, as they have globally (Stocker et al., 2013). Evidence suggests that the frequency of dry spells as well as daily rainfall intensity has increased (New et al., 2006). There is some evidence to suggest that droughts have become more intense and widespread over Southern Africa (Masih et al., 2014; New et al., 2006). The projected increase in temperature is expected to lead to more frequent droughts, particularly during periods of reduced rainfall (Engelbrecht et al., 2015; Shongwe et al., 2011; Stocker et al., 2013). The frequency of high fire danger days is projected to increase across Southern Africa which is consistent with the increases in heat-wave days (Engelbrecht et al., 2015).

Climate change is expected to alter the magnitude, timing and distribution of storms that produce flood events (Engelbrecht et al., 2013; Stocker et al., 2013). 


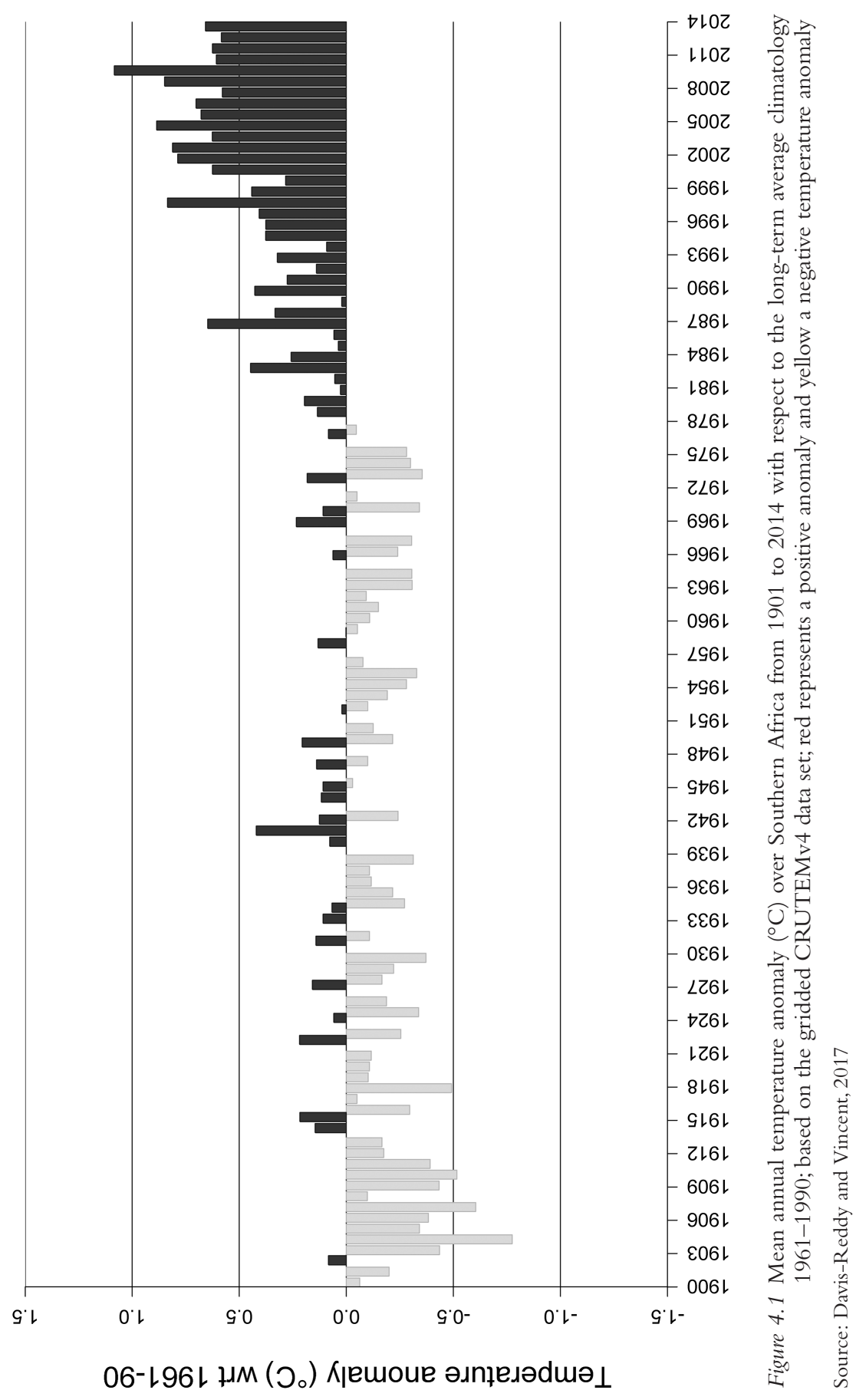




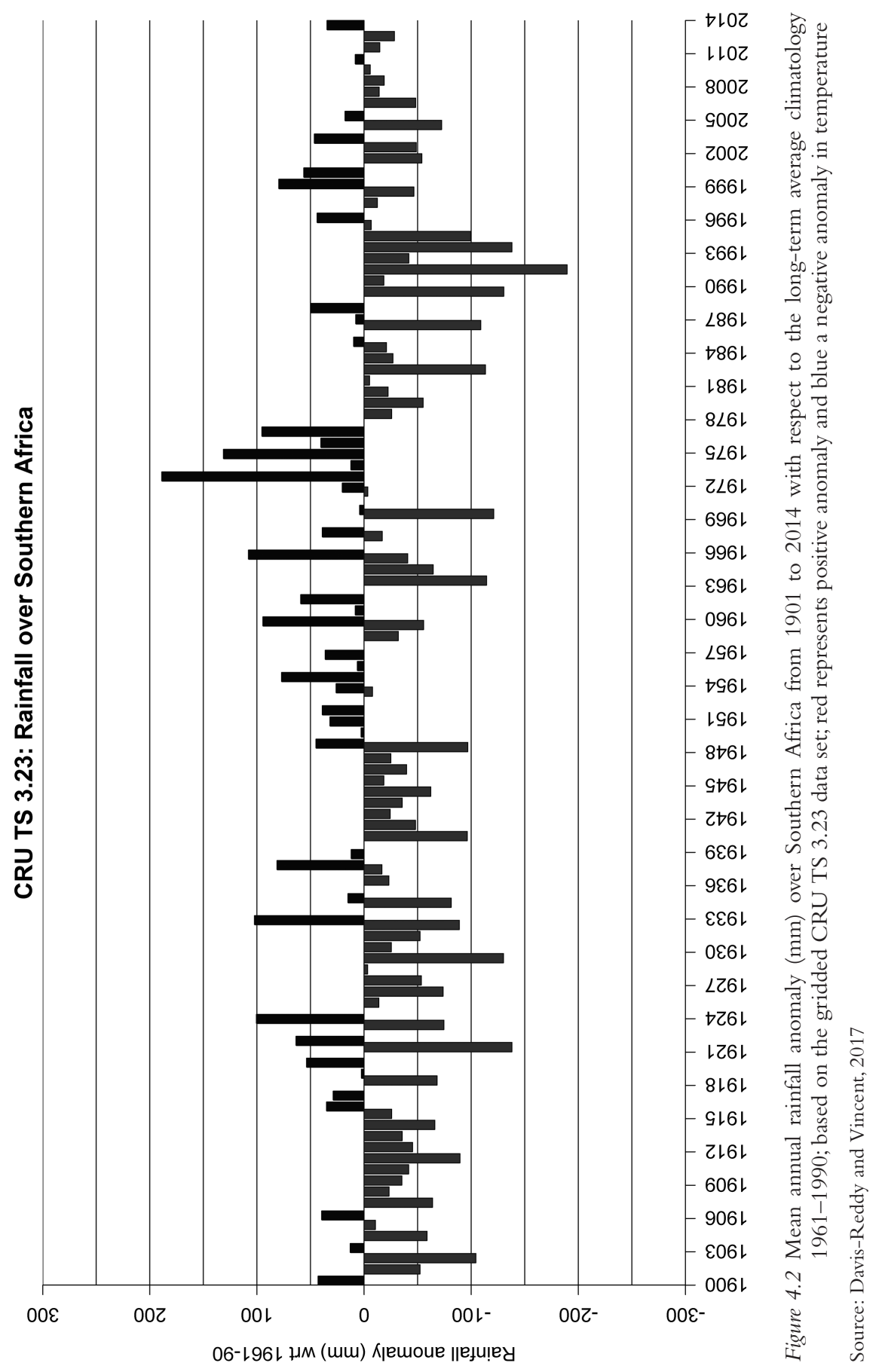



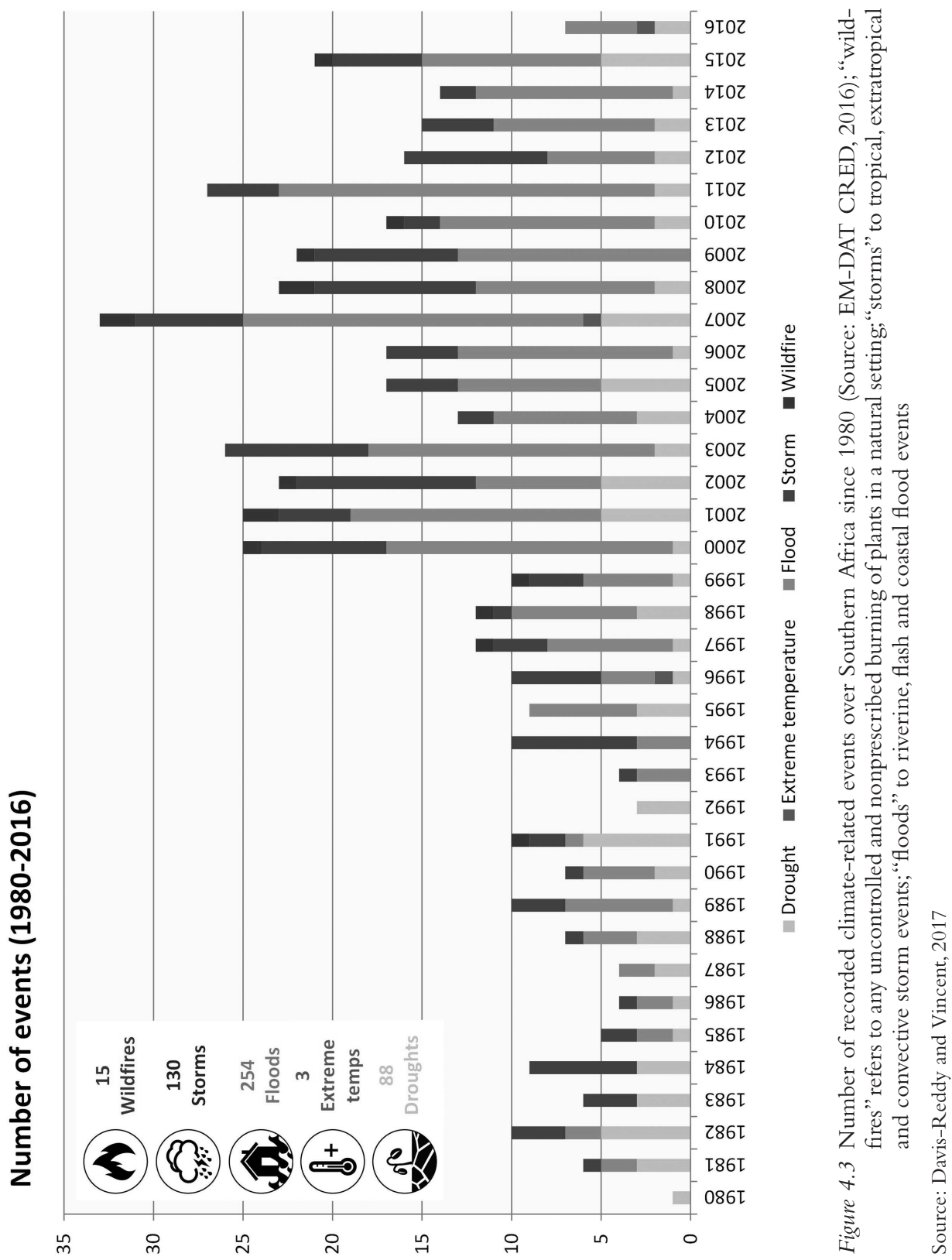
Tropical cyclones used to be rare in Southern Africa and of low intensity (Fitchett, 2018). The ocean temperature of the South Indian Ocean is creeping up, enhancing the intensity of cyclones. Moreover, the cyclone activity has moved southward where they are more likely to make landfall. Since 1994, category 5 storms in the South Indian Ocean have become more frequent and their frequency is likely to keep increasing. Most of this can be ascribed to an increase in sea surface temperature as a result of global warming. The greatest threat is to the northern half of Madagascar, Mozambique and to the islands of Reunion and Mauritius.

The SADC report (Davis-Reddy and Vincent, 2017) summarizes the climate projections for Southern Africa based on the CORDEX effort using over a dozen different Global Circulation Models with different downscaling approaches and two key development trajectories (RCPs). If greenhouse gases emissions continue to rise unmitigated, central Southern Africa will experience drier summers in the future. Parts of Tanzania and northern Mozambique will possibly be wetter. Winter rainfall in the Western Cape of South Africa is likely to decline in the future. Projections on rainfall tend to deviate among GCM projections and thus remain somewhat uncertain. The projections uniformly predict that the 21 st century will see continued increases in temperatures, somewhat less in the coastal regions.

The record of extreme events over the past 35 years in Southern Africa are summarized in Figure 4.3. Drought events were a regular occurrence whereas extreme temperatures occurred episodically. The frequency of floods and storms has increased drastically as have wildfires to some extent. The capacity to cope with these events in the region are limited, and the population is indeed highly vulnerable.

\section{Climate change and agriculture}

Agricultural in Southern Africa has limited adaptive capacity to the hazards of climate change due to endemic poverty and restricted capital and technology access and poor infrastructure greatly enhancing its vulnerability (Hachigonta et al., 2013; Parry, 2007). Climate change is also having a dramatic impact on food and nutrition security in most of sub-Saharan Africa (NOAA, 2007). The projected increase in rainfall variability, temperature and extreme events for the region will exacerbate the vulnerability of the predominantly rainfed systems on which food supply depends. Knox et al. (2012) conducted a meta-analysis of climate change on the yield of eight major crops in Africa and projected mean yield losses of $17 \%$ (wheat), 5\% (maize), 15\% (sorghum) and 10\% (millet) for Africa by mid-century. Dinesh et al. (2015) suggest that the area suitable for maize production could decline by 20 to $40 \%$ relative to the period from 1970 to 2000 . Maize is particularly sensitive to temperature, losing $1 \%$ for each growing day spent at a temperature above $30^{\circ} \mathrm{C}$ (Lobell et al., 2011). Wheat has an even lower temperature threshold value (Adhikari et al., 2015). 
Climate change will affect livestock productivity indirectly as well as directly. Climate change will diminish feed resources for livestock through changes in the primary productivity of crops, forages and rangelands. Changes in species composition in rangelands and some managed grasslands will affect the animal species that can graze them (Thornton et al., 2007). Domesticated species perform best at temperatures between 10 and $30^{\circ} \mathrm{C}$ and they will produce around 3 to $5 \%$ less for each $1^{\circ} \mathrm{C}$ increase above those levels. These temperatures are already exceeded in several regions.

According to Haywood (2015), the biophysical impacts of climate change can have a ripple effect along the whole agricultural value chain which spans input companies, farmers, distributors, agro-processing companies and retailers. The chapters in this book offer many guidelines on how to cope with the multiple stressors associated with climate change. Policymakers ignoring or denying the hazards associated with climate change do so at the peril of their society.

\section{Climate change and biotic stresses}

Crop loss will be complicated by a host of factors such as: 1) a decrease in host plant resistance; 2) a reduction in the efficacy of pesticides; 3 ) shifts in the effectiveness of ecosystem services that naturally regulate pest densities; 4) shifts in strains of fungi responsible for toxin production in postharvest; 5) arrival of alien pest species; and 6) enhanced weed growth and ultimate competition with crops (Muatinte and Van den Berg, 2018; Oerke and Dehne, 2004; Pratt et al., 2017; Tefera, 2012). Increased temperature associated with climate change will likely have a major impact on crop losses due to increased biotic stress (outlined in chapter 5 in this volume) from weeds, insects, fungal pathogens, viruses, nematodes and rodents. These pests cause yield loss at all stages in the production cycle from planting to postharvest with total harvest losses approaching 60\% (see chapter 6 in this volume). Yield losses of major staple crops (i.e., maize, rice, wheat and soybean), due to increased insect pests alone will expand by 10 to $25 \%$ for each degree of global mean surface warming (Deutsch et al., 2018; Henson et al., 2011).

These pests usually have enhanced development rates even with slight increases in daily temperatures, producing additional generations per cropping season and increased numbers of offspring. In addition, there will be shifts in pest species composition but also an increased spread of invasive pests into new zones with suitable climatic conditions. Furthermore, increased soil temperature, as affected by direct solar heating, will not only increase evapotranspiration but also the density of soil-borne pests in rhizosphere causing root system degradation that will affect water and nutrient uptake (Sikora, 2018).

Smallholder farmers in Africa will be more vulnerable to these consequences of climate change than large family and commercial farmers who have access to management options. Small farmers lack the necessary knowledge of pest biology and integrated management strategies and also face financial constraints (Biber-Freudenberger et al., 2016). Agriculture in Southern Africa, especially 
that of smallholders, will need to learn to cope with expected increases in biotic stresses. Therefore, it is of utmost importance that government institutions in the region develop response strategies and improve support to small-scale farmers to avoid crop losses and failures and ensure adequate food production.

\section{Conclusions and recommendations}

Climate change is a threat to food security (IPCC, 2019). If farmers are to cope with this threat, it is imperative to better understand the three intertwined food security and climate change challenges, namely 1) ensuring food security; 2) coping with the impact of climate change on agriculture; and 3) mitigating the impact of agriculture on climate change. To properly address these intertwined challenges, the Southern African agri-food system has to become more efficient and resilient at every scale from the farm to the regional food system. (Climate Smart Agriculture Sourcebook, FAO, 2013).

Resilience, the capacity of systems, and communities, to prevent, mitigate or cope with risks or recover from shocks, has various dimensions; biophysical, economic and social, operating at various scales. The manner in which the various dimensions and scales interact is crucial and needs to be better understood.

The current and emerging technologies to enhance agricultural transformation in Southern Africa and create resilient livelihoods are well documented in the various chapters in this book. They were selected for their significant role in traditional farming practices in Southern Africa and farming practices useful for climate change adaptation in agriculture in Southern Africa (IIED, 2011). Priority focus in the scaling up of proven technologies and practices is to reduce the vulnerability of farming in the region. The technologies described in this book as they relate to resilience include crop diversification of cereals and legumes, crop insurance schemes, drought or flood tolerant crop varieties, hazard-proof grain storage facilities, livestock shelters, strategic fodder reserves, bio-security of animal production systems, water reserves to buffer droughts and resilient animal breeding (FAO, 2011). However, traditional knowledge systems should be given due consideration in the technology packages.

Technologies and practices designed to address Disaster Risk Reduction (DRR) and climate change adaptation can be delivered as a coherent package of solutions, scaling up of proven risk reduction practices can be achieved through policies that support their systematic expansion. Climate Smart Disaster Risk Management (CSDRM) is designed to address the need to integrate disaster risk reduction and climate adaptation. There are 12 components of CSDRM comprising three action-oriented pillars (Davis-Reddy and Vincent, 2017) as follows: Pillar 1. Addressing changing disaster risks and uncertainties; Pillar 2. Enhancing adaptive capacity; and Pillar 3. Tackling poverty and vulnerability and their structural causes. Pillar 2 is of particular relevance here, since its key focus is on enhancing adaptive capacity and building resilience. This has policy implications for resource allocation for interventions at institutional and network levels that provide opportunities for learning, knowledge sharing for 
solving problems. In this context the factors essential for increasing resilience would include community participation, promoting diversity, acknowledging the importance of social values and structures in planning, preparedness and readiness. (Davies-Reddy and Vincent, 2017)

\section{References}

Adhikari, U., Pouyan Nejadhashemi, A. and Woznicki, S.A. (2015) Climate change and Eastern Africa: A review of impact on major crops. Food and Energy Security 4: 110-113.

Biber-Freudenberger, L., Ziemacki, J., Henri, E. Z., Tonnang, H.E.Z. and Borgemeister, C. (2016) Future risks of pest species under changing climatic conditions. PLoS. https://doi. org/10.1371/journal.pone.0153237.

Davis-Reddy, C.L. and Vincent, K. (2017) Climate Risk and Vulnerability: A Handbook for Southern Africa. CSIR, Pretoria, South Africa.

Deutsch, C.A., Tewksbur, J.J., Tigchelaar, M., Battisti, D.S., Merril, S.C., Huey, R.B. and Naylor, R.L. (2018) Increase in crop losses to insect pests in a warming climate. Science. 361: 916-919. doi:10.1126/science.aat3466.

Dinesh, D., Bett, B., Boone, R., Grace, D., Kinyangi, J., Lindahl, J., Mohan, C.V., RamirezVillegas, J., Robinson, R., Rosenstock, T., Smith, J. and Thornton, P. (2015) Impact of Climate Change on African Agriculture: Focus on Pests and Diseases. CGIAR Research Program on Climate Change, Agriculture and Food Security (CCAFS), Copenhagen, Denmark. www.ccafs.cgiar.org.

Engelbrecht, C., Engelbrecht, F. and Dyson, L. (2013) High resolution model-projected changes in mid-tropospheric closed-lows and extreme rainfall events over Southern Africa. International Journal of Climatology 33: 173-187.

Engelbrecht, F.A., Adegoke, J., Bopape, M.J., Naidoo, M., Garland, R.M., Thatcher, M., McGregor, J.L., Katzfey, J., Werner, M., Ichoku, C., et al. (2015) Projections of rapidly rising surface temperatures over Africa under low mitigation. Environmental Research Letters 10 .

FAO (2011) Save and Grow: A Policymaker's Guide to the Sustainable Intensification of Smallholder Crop Production. FAO, Rome.

FAO (2013) Climate-Smart Agriculture Sourcebook. FAO, Rome.

Fitchett, J. M. (2018) Recent emergence of CAT5 tropical cyclones in the South Indian Ocean. South African Journal of Science 114(11-12).

Hachigonta, S., Nelson, G.C., Thomas, T.S. and Sibanda, L.M. (2013) Southern African Agriculture and Climate Change. International Food Policy Research Institute, Washington DC, 337 .

Harris, I., Jones, P., Osborn, T. and Lister, D. (2013) Updated high-resolution grids of monthly climatic observations - the CRU TS3. 10 dataset. International Journal of Climatology 34: 623-642.

Haywood, L. (2015) Climate Change and Its Impact on Agribusiness, Natural Resources and the Environment. Council for Scientific and Industrial Research, Pretoria.

Henson, R. (2011) Climate Stabilization Targets: Emissions, Concentrations, and Impacts Over Decades to Millennia. National Academies Press, Washington, DC. www.nap.edu.

IIED. (2011) Adapting Agriculture with Traditional Knowledge. IIED Briefing.

IPCC. (2019). www.ipcc.ch/srccl-report-download-page/?fbclid=IwAR2sZJ_lluCSHJcedq9 Hx9pw2HF5f8iM-vzwYX3sxZOgIPP7-vYkV-ysJQU.

Knox, J., Hess, T., Daccache, A. and Wheeler, T. (2012) Climate change impacts on crop productivity in Africa and South Asia. Environmental Research Letters 7(3). 
Lobell, David B., Bänziger, M., Magorokosho, C. and Vivek, B. (2011) Nonlinear heat effects on African maize as evidenced by historical yield trials. Nature Climate Change 1: 42-45.

Masih, I., Maskey, S., Mussá, F. and Trambauer, P. (2014) A review of droughts on the African continent: A geospatial and long-term perspective. Hydrology and Earth System Sciences 18: 3635-3649.

Muatinte, B. and Van den Berg, J. (2018) The use of mass trapping to suppress population numbers of Prostephanus truncatus (Horn) (Coleoptera: Bostrichidae) in small scale farmer granaries in Mozambique. African Entomology 26: 301-316.

New, M., Kululanga, E., et al. (2006) Evidence of trends in daily climate extremes over Southern and West Africa. Journal of Geophysical Research 111(7): D14102.

NOAA (2007) Report on Climate Change, National Oceanic and Atmospheric Administration of the United States Department of Commerce. www.nws.noaa.gov/om/brochures/climate/ Climatechange.pdf.

Oerke, E.C. and Dehne, H.W. (2004) Safeguarding production - losses in major crops and the role of crop protection. Crop Protection 23: 275-285.

Osborn, T. and Jones, P. (2014) The CRUTEM4 land-surface air temperature data set: Construction, previous versions and dissemination via Google Earth. Earth System Science Data 6: 61-68.

Pandey, D.N., Gupta, A.K. and Anderson, D.M. (2003) Rainwater harvesting as an adaptation to climate change. Current Science 85: 46-59.

Parry, M.L. (2007) Climate Change 2007: Impacts, Adaptation and Vulnerability: Contribution of Working Group II to the Fourth Assessment Report of the Intergovernmental Panel on Climate Change. Cambridge University Press, Cambridge.

Pratt, C.F., Constantine, K.L. and Murphy, S.T. (2017) Economic impacts of invasive alien species on African smallholder livelihoods. Global Food Security 31-37.

Savary, S., Willocquet, L., Pethybridge, S.J., Esker, P., McRoberts, N. and Nelson, A. (2019) The global burden of pathogens and pests on major food crops. Nature - Ecology \& Evolution. Published online in Nature Ecology and Evolution.

Shongwe, M.E., van Oldenborgh, G.J., van den Hurk, B. and van Aalst, M. (2011) Projected changes in mean and extreme precipitation in Africa under global warming. Part II: East Africa. Journal of Climate 24(14): 3718-3733.

Sikora, R.A., Coyne, D., Hallmann, J. and Timper, P. (Eds) (2018) Plant Parasitic Nematodes in Subtropical and Tropical Agriculture. CABI, Wallingford, 3rd ed., 876.

Stocker, T., Qin, D. and Platner, G. (2013) Climate Change 2013: The Physical Science Basis: Working Group I Contribution to the Fifth Assessment Report of the Intergovernmental Panel on Climate Change. Summary for Policymakers. Cambridge University Press, Cambridge.

Tefera, T. (2012) Post-harvest losses in African maize in the face of increasing food shortage. Food Security 4(2): 267-277.

Thornton, P., Herrero, M., Freeman, H., Okeyo, A., Rege, E., Jones, P. and McDermott, J. (2007) Vulnerability, climate change and livestock - opportunities and challenges for the poor. Journal of Semi-Arid Tropical Agricultural Research 4(1). 